\title{
ETHICS AND AESTHETICS CRITERIA AS VALID SUPPORT TO RESEARCH
}

\author{
Darlei de Paula ${ }^{1}$ \\ Faculdade SEG - Sistema de Ensino Gaúcho
}

\begin{abstract}
This article aims to show the aesthetics and ethics values whose relation traces could be found in theological text studies. We use bibliographic review as methodology to this research. Considering these elements and how it was found we ask: how can we validate such elements to understand the theological text? When we are analyzing ethics behaviors can we consider the found results as intrinsic values in such discoveries and can it be compared in different times, in other words, it is available if we bring it out to our time without prejudice considering criteria. We know values and beliefs can change according different times, but the main question that translates our doubt is: how can we consider the ethical and aesthetical values described in different times avoiding damage then to be impartial in the research? In spite of lots of doubts rose, what can support on our research reading are historic and current images we can validate as support line to comparative analysis considering ethics and aesthetics values found. This text will be presented as communication in this event.
\end{abstract}

Keywords: Methodology. Ethics and research. Aesthetics and research. Theological methodology.

\section{CRITÉRIOS ÉTICOS E ESTÉTICOS COMO APOIO VÁLIDO PARA PESQUISA}

\section{Resumo}

Este artigo tem como principal objetivo mostrar a relação estética e o valor ético possível de ser encontrado em um texto teológico. Considerando se esses elementos foram encontrados e como podemos validar tais elementos para entender o texto teológico. Quando analisamos um comportamento estético, podemos considerar os resultados encontrados como valores intrínsecos em tais descobertas aos quais poderão ser comparados em diferentes momentos? Sabemos que valores e crenças podem mudar de acordo com as diferentes épocas, mas a questão principal que traduz a nossa dúvida é: Como podemos considerar os valores éticos e estéticos descritos em diferentes épocas? O que pode nos apoiar em nossa leitura para pesquisa teológica? A imagem histórica e atual como uma linha válida de análise comparativa.

Palavras-chave: Metodologia. Ética na investigação. Estética na investigação. Metodologia teológica.

${ }^{1}$ Doctor in Theology by Escola Superior de Teologia (Brasil) Master and Licensed in Philosophy by Pontifícia Universidade Católica do Rio Grande do Sul (Brasil). This text is part of Post-Doctoral research in Practical Theology applied to EST by supervision of Prof. Dr. Júlio Cezar Adam finished on July 30, 2018. 


\section{INTRODUCTION}

At first glance we ask: Is it possible we use the same methodology other human sciences in theological researches? Otherwise which would be the most appropriate methodology to investigate and make analysis on written or descriptive behaviors on theological focus? We try to answer these questions approaching bibliographical review on theological research considering to be helped by Philosophy readings as support.

So, todrive the hypothesis we make them as twofold out as following:

a) If the aesthetic relation and the ethical value were found we can consider it as validated element to understand the theological text. When we are analyzing an aesthetic behavior can we consider the found resultsas intrinsic values in such discoveries and can it be compared in different times? We know values and beliefs can change according different times, but the main question that translates our doubt is: How can we consider the ethical and aesthetical values described in different times? What can support our research reading?

b) Historical and current image as a valid line of comparative analysis. In case of considering the relationship between the historical and current image of the body in transformation, or transformed by external sociological factors can it retained the original main historical aspects by considering the basic features about perceived image as contemporary researches? In other words: Same features in different contexts can be useful for analysis in theological texts?

\section{THEOLOGY RESEARCH AND MEANING}

As starting point to solve our raised questions we can affirm that the Theology or to be more specific the theologian achieve keep as constant the searching for the actual meaning of God's Word drive to everybody. The theologian is a God's Word and life's faith researcher meaning ${ }^{2}$ (WICKS, 1999). As asserted to the following quote it varies according to the centuries and it specific characteristics:

$\mathrm{Na}$ história do cristianismo a investigação teológica assumiu uma diversidade de formas e seguiu métodos totalmente diferentes. Os teólogos trabalharam em contextos culturais muitíssimos diversos, como por exemplo, o império romano, antes e depois de Constantino; a cristandade medieval ocidental; a Europa no início da idade moderna, dividida pelo protestantismo e pela contra-reforma católica (WICKS, 1999, p. 14). ${ }^{3}$

\footnotetext{
${ }^{2}$ WICKS, Jared. Introdução ao Método Teológico. São Paulo: Loyola, 1999. p. 13.

${ }^{3}$ WICKS, 1999, p. 14. In the Christian history theological research had followed several different methods and forms. Theologians worked in a lot of different cultural contexts as for example: Roman Empire before and after
} 
While we can distinguish between intelligence and reflection as form applied to chose the ways that theologians could entrepreneur their attitudes to try to reveal the Theology mystery. We state that it is possible when we trace an auxiliary line as research sense forward to adopt procedures as scientific as philosophical as well. We believe that both are complement in the majority situations (CERVO, 2007). ${ }^{4}$

Ireneu de Lyon believed that the Theology was an intellectual activity which is acting inwards researcher to only one researches' faith schedule coordination was able to be taught in the Church (WICKS, 1999, p. 16). ${ }^{5}$ It makes a real meaning if we investigate the Holy Bible for instance.

But our objective is to show how we can identify marks that can shape, improve or outline behaviors by the results of practical Christian's everyday life such in biblical as any other support text analysis. In such case try to show what would be able to serve as our methodological support. We refer to bibliographical review studies. In the first hypothesis we appointed to aesthetical and ethical evidences.

\section{WHAT WE DEFINED AS ETHICAL AND AESTHETICAL WORTH IN TEXTUAL} ANALYSIS

At first glance we should reflect about how development of ethical term was had passed till we formulate our contemporary concept. It was not a huge advanced reach since XVIII century knew as the Illuminism phase (PESSINI, 2001). ${ }^{6}$

The categorical imperative formulated by Kant (1724-1804), was the most important universality validated formula conceited: "So act as if the maxim of your action were to become through your will a universal law of nature" (KANT, 2002, p. 38). ${ }^{7}$ In other words we do not have to do what we do not want others do to us.

Constantine; west medieval Christianity; Early modern Europe divided by Protestantism and Catholic CounterReform; (Translated by the author).

${ }^{4}$ CERVO. Amado L. Metodologia Científica. São Paulo: Pearson, 2007. p. 9.

${ }^{5}$ WICKS, 1999, p. 16.

${ }^{6}$ PESSINI, Leo. Bioética em tempo de incertezas. São Paulo: Loyola, 2001.

${ }^{7}$ KANT, Immanuel. Groundwork for the Metaphysics of Morals.New Haven: Yale Univ. Press, 2002. p. 38. 
We believe that it consist in give and receive respect in everyday life in our society. Writings about ethical concepts and classical exposures by specialists in Philosophy, Literature and Theology we found in a vast bibliographical list. But what is actually useful for us in this case on such philosophical text to apply on theological researches? It is what we need consider on practical. It is a signal we should afford to question on reading and examining texts.

Perhaps the worthy maxim thought and written by Kant quoted above is a good instrument to help us. Let's use such as line of reflection in our study. We can outline our way considering this Kant's thought.

Concerning to aesthetical reference we affirm that the aesthetical experience is a challenge because it make us to transcend to creation act as so the meaning we try to translate into the Art' Philosophy concept as well. According to Plato who composes tragedy in ways of imitation is thrice levels away from the king (the philosopher that contemplates the truth in itself to him must be the king.), (PLATO, 2018). ${ }^{8}$

In other words we can state that the aesthetic perception and experience are a continuous creation act someone can refer to life. It means which among artists, work of art and who contemplate the creation the provocation and contemplation are both indiscernible. ${ }^{9}$

\footnotetext{
Ce que nous disons là revient à un truisme: le monde du peintre est un monde visible, rien que visible, un monde presque fou, puisqu'il est complet n'étant cependant que partiel. La peinture réveille, porte à sa dernière puissance un délire qui est la vision même, puisque voir c'est avoir à distance, et que la peinture étend cette bizarre possession à tous les aspects de l'Être, qui doivent de quelque façon se faire visibles pour entrer en elle (MERLEAU-PONTY, 1964, p. 16). ${ }^{10}$
}

For Merleau-Ponty the painter lives his fascination as anyone who promotes the acting in gestures, traces who is the only one owner by himself, as we see quoted above. So it is a hard entrepreneur but not impossible to be analyzed. So we believe that we can consider it as the

\footnotetext{
${ }^{8}$ PLATO. The Republic: Book X. p. 461.In: http://www.idph.net/conteudos/ebooks/republic.pdf. Access in: 20 maio 2018.

${ }^{9}$ GILES, Thomas R. Introdução à Filosofia. São Paulo: EPU, 1979. p. 172.

${ }^{10}$ MERLEAU-PONTY, Maurice. LOe'il et L'esprit. Paris: Gallimard, 1964. p. 16. What we are saying here comes down to a truism: the world of the painter is a visible world, nothing else but visible, almost crazy world, it is quite complete but only partially. Painting awakens, brings to us its last power a delirium which is the very vision, to see is to have distance, and that painting extends this bizarre possession to all aspects of the Being, which must somehow be done visible to enter in its. (Translated by author)
} 
second tool to auxiliary the interpretation when we are analyzing data to solve hypothesis raised on Theological research but it do not dismiss the hermeneutic and exegetic traditional forms.

\section{DEFINING ETHICAL TRACES APPLIED TO THEOLOGY RESEARCH}

Though we can find a lot of ways to choose such philosophical line such as ethical as well aesthetical traces to be followed in our theological research it is correct to state that it is possible to make use of all systems. ${ }^{11}$ The researcher needs just identify which are the diversities characters whose would be able to be applied on such study. And keep in a safety way their logic main target.

The diversity of philosophical system need not mislead us. Theology is able to make some use of all systems. It can apply to its own ends every philosophical system which acknowledges the essential distinction between God and the world, spirit and matter, freedom and necessity (WEIDNER, 1898). ${ }^{12}$

Our questions arose to show how aspects or positions on different literary gender about texts that report behaviors' even biblical stories so theological illustrations whose don't mislead the truth on it. In other words try to present ethical clues identified within the text.

One of the main aspects appointed by Weidner is the psychological hermeneutics which shows the moral faculties (WEIDNER, 1898, p. 222). ${ }^{13}$ It helps us to understand "we require of the interpreter of the Holy Scripture, appears to us to be composed of faculties, tendencies or dispositions, and principles" (WEIDNER, 1898, p. 222). ${ }^{14}$

Considering moral faculties we therefore in order to accomplish the duties to understand that the written was made with high grade more about heart's intention than intellectual. So behaviors may be analyzed as acts from the heart, sensitiveness and simple human sense. In this form we can list the following:

A) Avoid to preconceived opinions. We ought to self questioning about the legality on the ethical clues possible to be understood and to draw as a paint of the real found situation discovered on text as task for be shown to the reader. We need pay attention to the "narrative structure, the circumstances" (MATERA, 1999, p. 16). ${ }^{15}$

\footnotetext{
${ }^{11}$ We dont' want to approach in a diachronic form as recommended by Wolfgang Schrage (1982) or synchronic form by Karl H. Schelkle (1973). We search to show a simple form as valid as complex one.MATERA, Frank. J. Ética do Novo Testamento. São Paulo: Paulus, 1999. p.17-18.

12 WEIDNER, Franklin. Theological Encyclopaedia. Chicago: Fleming H.Revell, 1898. p. 91.

${ }^{13}$ WEIDER, 1898, p. 222.

${ }^{14}$ WEIDER, 1898, p. 222.

${ }^{15}$ MATERA, Frank. J. Ética do Novo Testamento. São Paulo: Paulus, 1999. p. 16
} 
B) Show impartiality of mind and heart. We can consider through the impartiality the faith in search for the truth making parity between mind and reason and heart and feelings. So we can take distance of ourselves and try not to judge the traces could be found on the text. "This disposition required of the interpreter is the desire to acquire clear ideas" (MATERA, 1999, p. 223). ${ }^{16}$ The interpreter as the researcher need take care about the safe way choose to following when they are unfolding the terms and ideas expressed on behaviors describing or classifying values without expressing feelings or judging.

C) Allow so far as corrupt human nature as morally perfect as well as. "The interpreter should be not impartial and disinterested, but also, so far as corrupt human nature will allow, morally perfect" (MATERA, 1999, p. 16). ${ }^{17}$ The researcher needs take in his mind that his research ought to express clearness about ideas extracted from the text as a whole.

\section{DEFINING AESTHETICAL TRACES APPLIED TO THEOLOGY RESEARCH}

In the aesthetical studies we can afford for considering the original language text and its peculiarities which give into the translation same and even so more especial bright on the text worked.

We ought to discover within the meaning in the whole text and also step by step the beauty. It happens since the researcher specially the Theologian researcher attribute sense of value in other terms, if the Theologian prizes for the Word of God keeping in mind the beauty. As we can read:

In conjunction with the scientific culture, it is desirable also that there should be a cultivation of the aesthetic feeling. A sense of beautiful and of the ideal is needful in theology. No man without this can enter into the meaning of much that is most sublime in the Word of God (MATERA, 1999, p. 79). ${ }^{18}$

When we relate that aesthetic is linked to sense of beauty and nature we must consider that the related words and scenes on texts need be carried out of trace elements whose structural meaning presents an effective delivery of beauty to will read or listen to the Theologian rhetoric as well.

If the researcher in this case a Theologian researcher has the sense of aesthetic it will be easy found elements inwards the text that shows "love nature, and if he loves her aright, he will

\footnotetext{
${ }^{16}$ WEIDER, 1898, p. 223.

${ }^{17}$ WEIDER, 1898, p. 223.

${ }^{18}$ WEIDER, 1898, p. 79.
} 
find her a quicker to a fondness for painting, sculpture and architecture in their holy relations and use" (WEIDER, 1898, p. 79). ${ }^{19}$

In order to associate the art to philosophy of art or aesthetics we can consider the aesthetics more formal than philosophy of art because it treats about concepts and its meaning and the philosophy of art treats the forms in work of arts in instance (MORA, 1973) ${ }^{20}$ So it claims for special attention in the following points when we maneuver such questions as meaningful, intentionality and arbitrarily (ARANHA, 1995). ${ }^{21}$

a) There is a universe of meanings able to be discovered in a work which depends terms as: when, where and who is reading and making the entrepreneur role in the research text. In other words the Theologian's researcher point of view make the reading line according its experience and cultural knowledge acquired in his studies in vast possibilities of scientific fields included the aesthetics' worth.

b) The author's intentionality: Is it possible to discover such elements? We need self questioning if can we give attribution to the text respecting its initial proposal target

c) Arbitrary meaning: Is it possible to have acknowledgment about meaning that it is not possible to give attribution to the text? Which one? Such discoveries can be attributed to the text without the risk to impose arbitrarily meanings that are against it.

Analyzing these terms above we can advert that the connotative content is deeply related to the open or rupture process that can culminate in the development or transforming form to discover new art linguistics given opportunity of new comprehensions (ARANHA, 1995, p. $359) .{ }^{22}$

\section{HISTORICAL AND CURRENT IMAGE AS A VALID LINE OF COMPARATIVE} ANALYSIS

First of all, it is important to mention that we searched for supporting about history area considering only one aspect attributed to the founder of Historical School "Semler, who, although of a religious and sincere character was yet the real father of German Rationalism" (ARANHA, 1995, p. 217). ${ }^{23}$

\footnotetext{
${ }^{19}$ WEIDER, 1898, p. 79.

${ }^{20}$ MORA, José F. Diccionario de Filosofia. Buenos Aires: Editorial Sudamericana, 1973. p. 41.

${ }^{21}$ ARANHA, Maria L. A. Filosofando. São Paulo: Moderna, 1995. p. 358.

22 ARANHA, 1995, p. 359.

${ }^{23}$ WEIDER, 1898, p. 217.
} 
It is correct if we affirm that in this school some aspects to analyze the textual elements are linked to facts, usage and prejudice of the times. In such way the historical image can be freely and in a huge spectrum supported by both ethics and aesthetics elements as we have discussed in this text above.

Although till we assimilate such ideas and take a position have been passed by a long way and different focus determined by different Theologians who believed had traced the right line to discover the real situation on the text. As we can seen on hermeneutics history it was not easy and we can summarize in phases as we exemplify by the following quote:

In the development of the rationalism we may distinguish three principal hermeneutical phases: 1) The old, stiff rationalism represented by Paulus, explaining all the miracles bynatural causes. 2) Logical rationalism, represented by Wegscheider, laying down the principle that the Bible has no authority, andthat it containslesstruth than error. 3) Pietistic rationalism, represented by Wette, assigning great value to faith, but placing its foundation elsewhere than in the Bible (ARANHA, 1995, p. 217). ${ }^{24}$

According to Wider (1898), the enfeebled historical school seeks aid more than formerly from philological knowledge. In terms to simplify it is correct if we use practical hermeneutics as method to analyze the historical situation taking part of "conscientious, judicious, methodical, active and learned" elements found in the text (ARANHA, 1995, p. 218). ${ }^{25}$

Considering that we do not intend to exhaust nor create new theories about how it is possible to read and extract the meaning of the text useful nowadays in a historical perspective we can summing up the following tips that can help Theologian to work in his research as:

a) To be conscientiousis to be righteous;

b) To be judicious is to take criteria inwards textual meaning;

c) To be methodical means to choose appropriate ways to trace logical line of comprehension;d) active is to give value to actual situation we want to transform from such textual analysis; e) At last what can we extract to be learned with the text and useful for our research.

Therefore, after our brief passages by ethics, aesthetics and historical marks in this article we can affirm that it is not easy to choose only one way because the elements are

\footnotetext{
${ }^{24}$ WEIDER, 1898, p. 217.

${ }^{25}$ WEIDER, 1898, p. 218.
} 
immense spread in several subdivisions in the same great area. But we believe can pass to next step alluding to reach the conclusion about our research.

\section{CONCLUSIONS}

At first glance when we had projected to write about methodology applied to theological text research we thought to be easy to take a line of reasonable elements to build it. Besides considering only comprehension and clarification seemed to be easy task. Nevertheless it was not possible because it do not give any terms and situationsso clear. So this initial impulse was not able to transform anything in tips to future readers and researchers to improve their researches.

Then we had to give boundaries to our started point mapping the research target. But we believe we reach our main objective when we could consider the twofold hypothesis raised on introduction of this article. We hope to be able to solve them through text answering starting questions in a positive way to reach our proposal.

In the first hypothesis we considered the possibility that if the aesthetic relation and the ethical value were found we can consider it as validated element to understand the theological text since we can recognize through analyzing an aesthetic behavior and so consider the found resultsas intrinsic values in such discoveries whose can it be compared in different times or in other words, linked to historical characteristics.

We started considering that as values as beliefs can change according different times. We tried to show how can we consider the ethical and aesthetical values described in different times getting as support: a) Avoid to preconceived opinions; b) Show impartiality of mind and heart; c) Allow so far as corrupt human nature as morally perfect as well as.

In the second hypothesis we approach the historical and current image as a valid line of comparative analysis. In case of considering the relationship between the historical and current image of the behavior in transformation, or transformed by external sociological factors can it retained the original main historical aspects by considering the basic features about perceived image ascontemporary researches.

In other words: Same features in different contexts can be useful for analysis in theological texts considering the element listed in the last part of this article as to be conscientiousis to be righteous, to be judicious is to take criteria inwards textual meaning, to be methodical means to choose appropriate ways to trace logical line of comprehension, to be 
active is to give value to actual situation we want to transform from such textual analysis, and last what can we extract to be learned with the text and useful for our research.

\section{REFERENCES}

ARANHA, Maria L. A. Filosofando. São Paulo: Moderna, 1995.

CERVO. Amado L. Metodologia Científica. São Paulo: Pearson, 2007.

GILES, Thomas R. Introdução à Filosofia. São Paulo: EPU, 1979.

KANT, Immanuel. Groundwork for the Metaphysics of Morals. New Haven: Yale Univ. Press, 2002.

MATERA, Frank. J. Ética do Novo Testamento. São Paulo: Paulus, 1999.

MERLEAU-PONTY, Maurice. L'Oeil et L'esprit. Paris: Gallimard.

MORA, José F. Diccionario de Filosofia. Buenos Aires: Editorial Sudamericana, 1973.

PESSINI, Leo. Bioética em tempo de incertezas. São Paulo: Loyola, 2001.

PLATO. The Republic: Book X. p. 461. In:

http://www.idph.net/conteudos/ebooks/republic.pdf. Access in: 20 maio 2018.

WEIDNER, Franklin. Theological Encyclopaedia. Chicago: Fleming H.Revell, 1898.

WICKS, Jared. Introdução ao Método Teológico. São Paulo: Loyola, 1999. 